\title{
FACTORS ASSOCIATED WITH NUTRITIONAL STATUS OF CHILDREN UNDER FIVE YEARS OF AGE IN GUNUNGSITOLI IDANOI PRIMARY HEALTHCARE CENTER
}

\author{
Novrin Senselia Putri Ziliwu' ${ }^{1}$, Lina Dewi Anggraeni' ${ }^{1}$, Rosa Nora Lina ${ }^{2}$ \\ ${ }^{1}$ Sint Carolus School of Health Science, Jakarta, Indonesia \\ ${ }^{2}$ Eijkman-Oxford Clinical Research Unit, Sint Carolus School of Health Science, Jakarta, Indonesia \\ Correspondence Adress : Novrin Senselia Putri Ziliwu \\ Email : novrin.ziliwu@gmail.com
}

\begin{abstract}
The number of children under five years of age suffering from underweight was $28.0 \%$ in Gunungsitoli district. Out of six primary Healthcare centers in the district, Gunungsitoli Idanoi Primary Healthcare Center Healthcarewas one of the six primary healthcare centers with the highest malnutrition prevalence. Sixty-four children under five years of age there Healthcaresuffered from malnutrition. This study aimed to identify factors associated with the nutritional status of children under five in Gunungsitoli Idanoi Primary Healthcare Center, Gunungsitoli district. It was an analytical survey with a cross-sectional approach conducted in Gunungsitoli Idanoi Primary Healthcare Center in February 2019. Data were collected using a questionnaire. This study had samples as many as 246 mothers of children under five years of age selected using a purposive random sampling technique. The bivariate analysis indicates the nutritional status of children under five was significantly associated with mother's employment status ( $\mathrm{p}=0.043)$ and family size $(\mathrm{p}=0.015)$. While the nutritional status of children under five had no significant association with mother's knowledge of nutrition $(\mathrm{p}=0.485)$, mother's education $(\mathrm{p}=0.616)$, family income $(\mathrm{p}=0.511)$, infectious disease $(\mathrm{p}=0.913)$, and history of breastfeeding $(\mathrm{p}=0.847)$. Mother's employment status and family size affected the nutritional status of children under five. The primary Healthcare center should cooperate with stakeholders across sectors, especially conduct training for improving economic business skills of the people in the village, and promote family planning program for couples of childbearing age.
\end{abstract}

Keywords: Breastfeeding, children under five years of age, underweight, mother's knowledge, mother's employment.

\section{ABSTRAK}

Sebanyak 28,0\% balita yang mengalami masalah kekurangan gizi di Kota Gunungsitoli. Puskesmas Gunungsitoli Idanoi memiliki masalah kekurangan gizi yang paling tinggi dari enam puskesmas yang ada di Kota Gunungsitoli. Sebanyak 64 balita mengalami masalah kekurangan gizi. Penelitian ini bertujuan untuk mengetahui faktor-faktor yang berhubungan dengan status gizi anak balita di Puskesmas Gunungsitoli Idanoi, Kota Gunungsitoli. Penelitian merupakan survey analitik yang menggunakan pendekatan potong lintang. Penelitian ini dilakukan di Puskesmas Gunungsitoli Idanoi pada bulan Februari 2019. Data penelitian diperoleh menggunakan kuesioner. Jumlah sampel pada penelitian ini sebanyak 246 ibu yang memiliki balita usia di bawah lima tahun yang dipilih dengan teknik purposive sampling acak. Analisis bivariat menampilkan adanya hubungan pekerjaan ibu $(p=0,043)$ dan jumlah anak dalam keluarga $(p=0,015)$ dengan status gizi anak balita. Faktor yang tidak berhubungan adalah pengetahuan ibu $(p=0,485)$, pendidikan ibu $(p=0,616)$, pendapatan keluarga $(p=0,511)$, riwayat penyakit infeksi $(p=0,913)$, dan riwayat pemberian ASI eksklusif $(p=0,847)$. Pekerjaan ibu dan jumlah anak dapat mempengaruhi status gizi balita. Puskesmas tersebut perlu bekerja sama dengan pihak di berbagai lintas sektor terutama mengadakan pelatihan untuk meningkatkan keterampilan usaha ekonomi masyarakat di desa tersebut dan juga lebih menggalakkan program KB pada pasangan usia subur.

Kata Kunci: ASI eksklusif, balita, gizi kurang, pekerjaan ibu, pengetahuan ibu.

\section{INTRODUCTION}

Children under five years of age are groups prone to nutrition and disease (Salmah, 2018). Inadequate nutritional status in the first 1000 days of life can cause irreversible effects. The effects of malnutrition include apathy, speech disorder, low intelligence quotient (IQ) levels, and decreased sensory integration (Pawenrusi, 2016). Severe malnutrition in children under five years of age can affect brain development. 
The World Bank (2018) reports that the percentage of children under five suffering from underweight was $13.5 \%$ worldwide (The World Bank, 2018). Nutritional problems in these children are most commonly found in Africa and Asia (UNICEF, 2018). The nutritional status monitoring or Pemantauan Status Gizi (PSG) reported the prevalence of nutritional problems in Indonesia in 2017 was still the same as in 2016 where $3.8 \%$ children under five years of age suffered from severe underweight, while $14.0 \%$ of them had moderate underweight, and $1.8 \%$ of them were obese (Indonesian Ministry of Health, 2018). The Regional Midterm Development Plan for 2015-2019 states improving the health and nutritional status of the community is one of the main targets. The effort could reduce the percentage of malnutrition in children under five years of age to $17.0 \%$ in 2019 (Indonesian Ministry of Health, 2015).

Indonesia provinces with the highest malnutrition prevalence in 2017 were East Nusa Tenggara (28.3\%), Central Sulawesi (26.1\%), West Kalimantan (25.9\%), West Sulawesi (24.8\%), and Aceh $(24.8 \%)$. North Sumatera was ranked $19^{\text {th }}$ out of 34 provinces for the highest malnutrition prevalence (Indonesian Ministry of Health, 2018). In 2017, it increased to $18.4 \%$ compared to the previous year. As much as $5.3 \%$ malnutrition was severe underweight, and $13.1 \%$ malnutrition was moderate underweight (Indonesian Ministry of Health, 2018).

The malnutrition prevalence in Gunungsitoli district was at $28.0 \%$ in 2017 Indonesian Ministry of Health, 2018). HealthcareOut of six primary healthcare centers in Gunungsitoli district, Gunungsitoli Idanoi Primary Healthcare Centre has the highest malnutrition prevalence in children under five years of age. There were 64 Healthcaremalnourished children reported there.
Globally, 5.6 million children under five years of age died in 2016 (WHO, 2017). The WHO explains that children suffering from malnutrition are mostly under five years old, and they have a higher risk of death than older children. Malnutrition caused around half of deaths among children under five years of age. It causes children under five years of age more prone to common infectious disease, increases the frequency and severity of infection, and slows recovery (UNICEF, 2018).

Deaths of children (aged 0-4 years) could be minimized by ending malnutrition in all forms (WHO, 2017). The United Nations Development Programme (UNDP) asserts that this way is one of the Sustainable Development Goals (SDGs) which aim to end all forms of hunger in the world (UNDP, 2018). It targets a decrease in deaths of children (aged 0-4 years) by 10 million between 2017-2030 (UNICEF, 2018). The mortality rate targeted was at least 25 per 1,000 live births in each country (WHO, 2017).

Many factors contribute to achieving good nutritional status in children under five years of age. Lack of food consumption is not only a major cause of nutritional problems. In several developing and underdeveloped countries, diarrhea is a major factor for malnutrition (Hockenberry \& Wilson, 2015). Other factors include poor environmental sanitation, inadequate knowledge of child care, illiterate parents, economic and political factors, climate, types of food consumed based on culture and religion, and lack of adequate food (Hockenberry and Wilson, 2015). Mother's knowledge, mother's education, family income, mother's employment status, family size, mother's attitude, parenting, and infectious disease are other factors affecting nutritional status of children under five years of age (Handayani, 2017).

The nutrition program coordinator in Gunungsitoli Idanoi Primary Healthcare Center explained that low income of 
parents and lack of knowledge of nutrition including exclusive breastfeeding and types of MP-ASI may impact children's nutritional status. Besides, more children in a family may cause parents not aware of food consumption patterns for their children.

Putri, et al. (2015) have conducted similar research in the working area of the Nanggalo Padang Primary Healthcare Center. They note that mother's education, family income, mother's occupation, parenting, and family size affected the nutritional status of children under five years of age. However, another previous study shows different results. It points out that infectious diseases have an association with the nutritional status of under-five children. Birth spacing, maternal education, nutrition care patterns, and maternal occupation do not influence the nutritional status of under-five children.

These different findings of other previous studies have inspired this recent study, to identify factors associated with the nutritional status of children under five years of age in Gunungsitoli Idanoi Primary Healthcare Center.

\section{METHODS}

This study was conducted in Gunungsitoli Idanoi Primary Healthcare Center in February 2019. This study was quantitative research with a cross-sectional approach. The research population involved mothers of children under five years of age in the working area of Gunungsitoli Idanoi Primary Healthcare Center. Finally, 246 mothers as samples were selected using a purposive random sampling technique by considering the inclusion and exclusion criteria. To be selected as the samples, mothers should be 20-35 years old, have the last children aged 1-4 years live in the working area of Gunungsitoli Idanoi Primary Healthcare Center, and be willing to participate in this study. Mothers who suffered from diseases (URI, diarrhea, and malaria) and refused to participate were excluded from the study.

This study employed a modified questionnaire that consisted of 21 questions regarding mother's knowledge of nutrition needs for children under five years of age, mother's education, mother's employment, family size, family income, history of infectious disease, and history of exclusive breastfeeding. Previously, the validity and reliability of this questionnaire were tested on people with similar inclusion criteria outside the research samples. using the Cronbach's alpha of 0.802 , that indicated a perfect validity level. This study has passed the ethical review by the Ethics Commission from Faculty of Medicine, University of Indonesia with the letter number of 1276/UN2.F1/ETIK/2018 and research permit from Gunungsitoli District Health Office with the permit number of 440/494/PSDK-SDMK/I/2019. This study performed chi-square tests for analyzing the variables (mother's education, mother's employment, family size, history of infectious diseases, and history of exclusive breastfeeding) and Fisher test for analyzing other variables (mother's knowledge and family income).

\section{RESULTS \\ Baseline Characteristics}

Table 1 presents characteristics of 246 respondents participating in this study. There were 169 respondents $(68.7 \%)$ with good knowledge about nutrition needs of children under five years of age, and 184 respondents $(74.8 \%)$ had primary education. Regarding employment and family size, 205 respondents (83.3\%) did not work, and 172 respondents $(69.9 \%)$ had more than 2 children. This study also finds 243 respondents $(98.8 \%)$ had less than IDR $2,132,188 /$ month, and 207 mothers $(84.1 \%)$ had children with a history of infectious disease in the last three months. Further, 133 mothers $(54.1 \%)$ did not give exclusive breastfeeding, and 194 mothers (78.9\%) had children with good nutrition status. 
Table 1 Frequency Distribution of Respondents' Characteristics

\begin{tabular}{lll}
\hline \multicolumn{1}{c}{ Baseline Characteristics } & Frequency (n) & Percentage (\%) \\
\hline Mother's Knowledge & 22 & 8.9 \\
$\quad$ Poor & 169 & 68.7 \\
$\quad$ Moderate & 55 & 22.4 \\
GoodMother's Education & & \\
$\quad$ Primary education & 184 & 74.8 \\
$\quad$ (Elementary School and Middle School) & & \\
$\quad$ Higher education & 62 & 25.2 \\
$\quad$ (High School and College) & & \\
Mother's Employment & & \\
$\quad$ Unemployed & 205 & 83.3 \\
$\quad$ Employed & 41 & 16.7 \\
Family Size & & \\
$\quad>2$ & 172 & 69.9 \\
$\quad \leq 2$ & 74 & 30.1 \\
Family Income & & \\
$\quad$ IDR 2,132,188/months & 243 & 98.8 \\
$\quad$ IDR 2,132,188/months & 3 & 1.2 \\
History of Infectious Disease & & \\
$\quad$ Yes & 207 & 84.1 \\
$\quad$ No & 39 & 15.9 \\
History of exclusive & & \\
breastfeeding & 133 & 54.1 \\
$\quad$ No & 113 & 45.9 \\
$\quad$ Yes & 4 & 1.6 \\
Nutritional Status & 48 & 78.9 \\
$\quad$ Severe underweight & 194 & \\
$\quad$ Moderate Underweight & & \\
$\quad$ Good & & \\
& &
\end{tabular}

\section{Mother's Knowledge}

Table 2 shows that of 22 mothers who had poor knowledge, 4 mothers $(18.2 \%)$ had children suffering from severe underweight and moderate underweight, and 18 mothers $(81.8 \%)$ had children with good nutritional status. While of 224 mothers who were well-informed about nutrition needs for children under five years of age, 48 mothers (21.4\%) had children with severe underweight and moderate underweight, and 176 mothers $(78.6 \%)$ had children with good nutritional status.

\section{Mother's Education}

of the results show out of 184 mothers who completed primary education,
37 mothers (20.1\%) had children with severe underweight and moderate underweight, and 147 mowthers (79.9\%) had children with good nutritional status. While among 62 mothers with higher education, 15 mothers $(24.2 \%)$ had children with severe underweight and moderate underweight, and 47 mothers $(75.8 \%)$ had children with good nutritional status.

\section{Mother's Employment}

Table 2 illustrates that of 205 unemployed mothers, 38 mothers $(18.5 \%)$ had children who experienced severe underweight and moderate underweight, and 167 mothers (81.5\%) had children with good nutritional status. Further, this study finds among 41 working mothers, 14 
mothers $(34.1 \%)$ had children with severe underweight and moderate underweight, and 27 mothers $(65.9 \%)$ had children with good nutritional status.

\section{Family Size}

The results show among 172 mothers who had more than two children, 44 mothers (25.6\%) had children with severe underweight and moderate underweight, and 128 mothers (74.4\%) had children with good nutritional status. While of 74 mothers bearing $\leq 2$ children, 8 mothers $(10.8 \%)$ had children with severe underweight and moderate underweight, and 66 mothers $(89.2 \%)$ had children with good nutritional status.

\section{Family Income}

In Table 2, the results show of 243 mothers with family income of less than IDR 2,132,188/month, 51 mothers (21.0\%) had children suffering from severe underweight and moderate underweight, and 192 mothers (79.0\%) took care of children with good nutritional status. While 3 mothers with family income of more than or equal to IDR $2,132,188 /$ month, only 1 mother $(33.3 \%)$ had a child with severe underweight and moderate underweight, and two others $(66.7 \%)$ had children with good nutritional status.

\section{History of Infectious Disease}

This study also suggests among 207 mothers whose children had a history of infectious diseases, 43 mothers (20.8\%) had children with severe underweight and moderate underweight, and 164 mothers (79.2\%) had children with good nutritional status. Whereas, among 39 mothers whose children had no history of infectious disease, 9 mothers $(23.1 \%)$ had children with severe underweight and moderate underweight, and 30 mothers $(76.9 \%)$ had children with good nutritional status.

\section{History of Exclusive Breastfeeding}

Regarding the history of exclusive breastfeeding practice, among 133 mothers who did not breastfeed their children, and 27 mothers (20.3\%) had children with severe underweight and moderate underweight, and 106 mothers $(79.7 \%)$ had children with good nutritional status. Whereas, of 113 respondents who breastfed their children, 25 mothers $(22.1 \%)$ had children with severe underweight and moderate underweight, and 88 mothers (77.9\%) had children with good nutritional status.

\section{DISCUSSION}

\section{Relationship between mother's knowledhe and nutritional status of children under five years of age}

The results indicate that nutritional status of children under five years old had no relationship with mother's knowledge. Malnutrition roccured not only to mothers who lacked knowledge but also to those with enough knowledge. Mothers with poor knowledge were 0.815 times more likely to have malnourished children than those with adequate knowledge. It is in line with the research conducted by Apriliana and Rakhma (2017); Lestari, Sarbini, and Rakhma (2015) which indicate that mother's knowledge was not associated with the nutritional status of children under five years of age. These studies find wellinformed mothers turned out to have underweight children under five years old. However, these results are contradictory to other two studies which conclude that the nutritional status of children under five years of age could be affected by the level of mother's knowledge (Pawenrusi, 2016; Suryani, 2017).

Knowledge about nutrition needs for children under five years of age will greatly affect actions that mothers will take (Pawenrusi, 2016). Better knowledge will improve the ability of mothers to choose and serve nutritious food for their children. 
Lack of mother's knowledge and action for nutritious food serving will cause malnutrition in children under five years of age (Khotimah and Kuswandi, 2014). Good knowledge without actions will not be effective to end malnutrition in all forms. Most mothers said that they knew the importance of adequate nutrition for their child's growth and development, but they sometimes did not apply it in actions. For example, mothers know snacks are not good for children's health, but they sometimes forget to limit snacking time and follow children's snacking habit. It cause children lose appetite of nutritious food.

Table 2. Analysis of Relationship between Respondents' Characteristics and the Nutritional Status of Children Under Five Years of Age

\begin{tabular}{|c|c|c|c|c|c|c|c|c|}
\hline \multirow[t]{2}{*}{ Baseline Characteristics } & \multicolumn{2}{|c|}{\begin{tabular}{l}
\multicolumn{1}{c}{ Severe } \\
underweight \\
+ \\
Moderate \\
underweight
\end{tabular}} & \multicolumn{2}{|c|}{$\begin{array}{c}\text { Good } \\
\text { Nutritional }\end{array}$} & \multicolumn{2}{|c|}{ Total } & \multirow[t]{2}{*}{ P-value } & \multirow[t]{2}{*}{$\begin{array}{l}\text { OR } \\
95 \%)\end{array}$} \\
\hline & $\mathbf{n}$ & $\%$ & $\mathbf{N}$ & $\%$ & $\mathbf{n}$ & $\%$ & & \\
\hline Mother's Knowledge & & & & & & & & 0.815 \\
\hline Poor & 4 & 18.2 & 18 & 81.8 & 22 & 100 & 1.000 & $(0.263-$ \\
\hline Moderate + Good & 48 & 21.4 & 176 & 78.6 & 224 & 100 & & $2.521)$ \\
\hline Mother's Education & & & & & & & & 0.789 \\
\hline Primary education & 37 & 20.1 & 147 & 79.9 & 184 & 100 & 0.616 & $(0.398-$ \\
\hline Higher education & 15 & 24.2 & 47 & 75.8 & 62 & 100 & & $1.563)$ \\
\hline Mother's Employment & & & & & & & & 0.439 \\
\hline Unemployed & 38 & 18.5 & 167 & 81.5 & 205 & 100 & 0.043 & $(0.210-$ \\
\hline Employed & 14 & 34.1 & 27 & 65.9 & 41 & 100 & & $0.916)$ \\
\hline Family Size & & & & & & & & 2.836 \\
\hline$>2$ & 44 & 25.6 & 128 & 74.4 & 172 & 100 & 0.015 & $(1.262-$ \\
\hline$\leq 2$ & 8 & 10.8 & 66 & 89.2 & 74 & 100 & & $6.372)$ \\
\hline Family Income & & & & & & & & 0.531 \\
\hline$<$ IDR 2,132,188/month & 51 & 21.0 & 192 & 79.0 & 243 & 100 & 0.511 & $(0.047-$ \\
\hline$\geq$ IDR $2,132,188 /$ month & 1 & 33.3 & 2 & 66.7 & 3 & 100 & & $5.976)$ \\
\hline \multicolumn{9}{|l|}{ History of Infectious } \\
\hline Disease & & & & & & & & 0.874 \\
\hline Yes & 43 & 20.8 & 164 & 79.2 & 207 & 100 & 0.913 & $(0.386-$ \\
\hline No & 9 & 23.1 & 30 & 76.9 & 39 & 100 & & 1.979) \\
\hline \multicolumn{9}{|l|}{ History of Exclusive } \\
\hline Breastfeeding & & & & & & & & 0.897 \\
\hline No & 27 & 20.3 & 106 & 79.7 & 133 & 100 & 0.847 & $(0.486-$ \\
\hline Yes & 25 & 22.1 & 88 & 77.9 & 113 & 100 & & $1.655)$ \\
\hline
\end{tabular}

\section{Relationship between mother's education and nutritional status of children under five years of age}

This study reports no significant relationship between nutritional status of children under five years of age and mother's education. Mothers with primary education were 0.789 times more likely to have malnourished children than those with higher education. Sholikah et al. (2017);
Munawaroh (2015) strengthen the nutritional status of children under five years old was not affected by mother's education. The result differs from the research conducted by Putri, et al. (2015); Suryani (2017). They discover mother's education did not have a meaningful relationship with the nutritional status of children under five years of age. 
Mothers who completed higher education levels have better abilities to increase knowledge, attitude, and behavior (Suryani, 2017). Education significantly contributes to the ability of individuals to interpret knowledge acquired. Good information and knowledge are not only available in formal education but also mass media, integrated service post, midwives, health cadres, the environment such as family and colleagues (Pratiwi, et al., 2015).

This study suggests most highly educated mothers did not always have good knowledge of nutrition. It was proven by the fact that mothers with primary education could get higher scores than mothers with higher education. It shows that all mothers who completed one of education levels still had good knowledge of nutrition which would affect the nutritional status of children under five years of age.

Moreover, mothers with higher education had children with better nutrition status. As they had more agility to utilize technology and counseling services in healthcare centers, they could access and understand information easily related to balanced nutrition for pregnancy.

\section{Relationship between mother's employment and nutritional status of children under five years of age}

This study discovers a relationship between mother's employment and nutritional status of children under five years old. It indicates that unemployed mothers had0.439 times more possibility of having malnourished children than working mothers. Other studies also find similar results (Putri et al., 2015; Khotimah and Kuswandi, 2014).

Meanwhile, studies by Sholikah et al. (2017); Rumende, et al. (2018) show slightly different results. They explain that the nutritional status of children under five years old was not related to mother's work. Further, they report working mothers were more likely to have children with poor nutritional status.
Types of parents' work would generate different amount of income to meet family's needs, such as nutritious food (Adriani \& Wirjatmadi, 2014). Working mothers are more likely to afford for the adequate nutritional intake of their children (Supariasa, et al., 2016).

\section{Relationship between family size and nutritional status of children under five years of age}

The analysis provides an association between family size and nutritional status of children aged 0-4 years. This present study explains mothers who had more than 2 children were 2.836 times more likely to have malnourished children than mothers who had less than or equal to 2 children. Studies conducted by Putri, et al. (2015); Suryani (2017) elaborate by stating that family size had a relationship with nutritional status of children under five years old. Families with a large number of family members tend to have malnourished children (Adriani and Wirjatmadi, 2014). However, studies done by Karundeng, et al. (2015); Mahmood, et al. (2016) who discover no significant relationship between family size and nutritional status of children under five years of age.

A large number of children in a family can affect the quantity of food served, and family have to have enough income to meet this need. Families with nutritious food consumption commonly have fewer or equal numbers of 2 children. Families with fewer members will be able to provide nutritious food better for their family members. The capability of nutritious food serving depends a lot on family income.

\section{Relationship between family income and nutritional status of children under five years of age}

This study reports that there was no significant relationship between family income and nutritional status of children under five years of age. Mothers who 
earned less than IDR 2,132,188/month were 0.531 times more likely to have malnourished children than those earning more than or equal to IDR $2,132,188 /$ month. Other research discover the same findings (Ratufelan, et al. 2018).

Meanwhile, some other studies find a relationship between family income and nutritional status of children aged 0-4 years (Putri et al., 2015; Pawenrusi, 2016). Low family income cause parents not afford to provide nutritious food as required in the family. While richer family income are more able to provide good quality food in good quantity (Adriani and Wirjatmadi, 2014). This present study indicates that families earning less or equal to IDR $2,132,188$ /month had children with good nutritional status that is also determined by dietary patterns. For example, mothers who are unable to buy chicken usually cook eggs which also contain protein.

\section{Relationship between history of infectious disease and nutritional status of children under five years of age}

This study reveals that history of infectious disease had no relationship with nutritional status of children under five years of age. It further elaborates children who had a history of infectious disease had 0.874 times more possibilities of malnutrition.

This finding accords with that of other studies which find similar results (Rohimah, et al., 2015; Arum, et al. 2017). In contrast, Handayani finds a relationship between history of infectious disease and nutritional status of children aged 0-4 years (Handayani, 2017). It is also in line with other research that shows similar results (Ratufelan et al., 2018).

Decreased appetite tends to occur in children under five years old who ever had infectious diseases, and this can lead to malnutrition (Par'i, 2014). Those with history of infectious disease tend to have good nutritional status as their dietary needs should be fulfilled for recovery. Children with no history of infectious diseases possibly experience malnutrition if they do not receive adequate nutritious food intake.

\section{Relationship between history of exclusive breastfeeding and nutritional status of children under five years of age}

Additionally, there was no significant association between history of exclusive breastfeeding and nutritional status of children under five years old. Children who did not receive exclusive breastfeeding were 0.897 times more likely to malnourished compared to those who received exclusive breastfeeding.

Other studies point out similar findings as this study does (Mahmood et al., 2016; Kowureng, et al. 2018). However, different results were found in some studies which show history of exclusive breastfeeding had no relationship to nutritional status of children under five (Andriani, et al. 2015; Pratiwi et al., 2015).

Exclusive breastfeeding should be done in the first 6 months of baby's life without additional food and drink (Asih and Risneni, 2016). Exclusive breastfeeding for babies can affect their nutritional status (Ningrum, 2014). However, this present study proves contrast findings which state most children who received exclusive breastfeeding were also malnourished. It needs to highlight the fact that the quality and quantity of breast milk depend on mother's food consumption. Nursing mothers need more calories around 200 to 500 calories per day, intakes of calcium, minerals, and fat-soluble vitamins. When mothers cannot meet these nutrient needs, they will not perform breastfeeding well.

Mothers have to breastfeed their babies for 8-12 times during 24 hours with a duration of 3-4 hours. The average time to breastfeed is 30-40 minutes. Some respondents said that they breastfed their children only when they are crying. Then they would stop breastfeeding when the children stopped crying. Such breastfeeding practice is not the ideal one as children do not receive optimal duration of breastfeeding. 


\section{CONCLUSION}

This study concludes that the majority of mothersw in the working area of Gunungsitoli Idanoi Primary Healthcare Center had good knowledge about nutrition for babies, completed primary education, but they were mostly unemployed and had more than 2 children, earned less than IDR $2,132,188$ /month. The majority of their babies had a history of infectious disease in the last three months, did not receive exclusive breastfeeding, but had good nutrition status.

Primary healthcare centers should always maintain and enhance cooperation with stakeholders across sectors to improve the community economic status. Empowering mothers to create job opportunities may contribute to increasing their family income which allow them to afford nutritious food. Besides, it is required to promote family planning programs for couples of childbearing age to reduce birth rates in the working area of Gunungsitoli Idanoi Primary Healthcare Center. Primary healthcare centers could provide counseling services related to family planning to increase mother's awareness of family planning. Additionally, villages should adopt family planning village goals to achieve contraceptive prevalence (CPR) targets set by the government. The establishment of family planning village is expected to reduce population rates which could burden family's economic condition

\section{REFERENCES}

Adriani, M., \& Wirjatmadi, B. (2014). Gizi dan Kesehatan Balita. Jakarta: PRENAMEDIA GROUP.

Andriani, R., Wismaningsih, E. R., \& Indrasari, O. R. (2015). Hubungan Pemberian ASI Eksklusif dengan Kejadian Status Gizi Kurang pada Balita Umur 1-5 Tahun. Jurnal Wiyata, 2(1), 44-47.

Apriliana, W. F., \& Rakhma, L. R. (2017).
Faktor-faktor yang berhubungan dengan Status Gizi Balita yang mengikuti TFC di Kabupaten Sukoharjo. Media Publikasi Penelitian, 15(1), 1-8.

Arum, R., Rahfiludin, M. Z., \& Nugraheni, S. A. (2017). Faktor-faktor yang berhubungan dengan terjadinya Gizi Kurang pada Anak Balita Usia 24-59 Bulan (Studi di Wilayah Kerja Puskesmas Halmahera Kota Semarang Tahun 2017. Jurnal Kesehatan Masyarakat, 5(3), 175-185.

Asih, Y., \& Risneni. (2016). Asuhan kebidanan Nifas dan Menyusui. Jakarta: CV. Trans Info Media.

Handayani, R. (2017). Faktor-faktor yang berhubungan dengan Status Gizi pada Anak Balita. Journal Endurence, 2(2), 217-224. https://doi.org/10.22216/jen.v2i2.174 2

Hockenberry, M. J., \& Wilson, D. (2015). Wong's Nursing Care of Infants and Children (10th ed.). St. Louis: Elsevier.

Karundeng, L. R., Ismanto, A. Y., \& Kundre, R. (2015). Hubungan Jarak Kelahiran dan Jumlah Anak dengan Status Gizi Balita di Puskesmas Kao Kecamatan Kao Kabupaten Halmahera Utara. EJournal Keperawatan (e-Kep), 3(1), 1-9.

Indonesian Ministry of Health. (2015). Rencana Strategis Kementrian Kesehatan Tahun 2015-2019. Jakarta: Kementrian Kesehatan RI.

Indonesian Ministry of Health. (2018). Buku Saku Pemantauan Status Gizi Tahun 2017. Jakarta: Kementrian Kesehatan RI.

Khotimah, H., \& Kuswandi, K. (2014). Hubungan Karakteristik Ibu dengan Status Gizi Balita di Desa Sumur Bandung Kecamatan Cikulur Kabupaten Lebah Tahun 2013. Jurnal Obstretika Scientia, 2(1), 146-162.

Kowureng, F. C., Kapantow, N. H., \& Punuh, M. I. (2018). Hubungan antara Riwayat Pemberian ASI dengan Status 
Gizi pada Anak Usia 24-59 Bulan di Wilayah Kerja Puskesmas Touluaan Kabupaten Minahasa Tenggara. Jurnal Kesmas, 7(4).

Lestari, P., Sarbini, D., \& Rakhma, L. R. (2015). Hubungan Pengetahuan dan Sikap Ibu tentang Makanan Balita di Desa Malangjiwan, Kecamatan Colomadu, Kabupaten Karanganyar.

Mahmood, S., Nadeem, S., Saif, T., Mannan, M., \& Arshad, U. (2016). Nutritional Status and Associated Factors in Under-five Children of Rawalpindi. J Ayub Med Coll Abbottabad, 28(1), 67-71.

Munawaroh, S. (2015). Pola Asuh mempengaruhi Status Gizi Balita. Jurnal Keperawatan, 6(1), 44-50. https://doi.org/10.22219/jk.v6i1.2851

Ningrum, A. S. (2014). Hubungan Pemberian ASI Eksklusif dengan Status Gizi Balita Usia 12-59 Bulan di Posyandu Dewi Sartika Candran Sidoarum Sleman.

Par'i, H. M. (2014). Penilaian Status Gizi. Jakarta: EGC.

Pawenrusi, E. P. (2016). Factors Related to the Nutritional Status of Children in Area Served by the Pattingalloang Health Center, Makassar. Pakistan Journal of Nutrition, 15(4), 333-336. https://doi.org/10.3923/pjn.2016.333. 336

Pratiwi, R. H., Suyatno, \& Aruben, R. (2015). Faktor-faktor yang berhubungan dengan berat-kurang (Underweight) pada Balita di Perkotaan dan Perdesaan Indonesia berdasarkan Data Riskesdas Tahun 2013. Jurnal Kesehatan Masyarakat3, 3(2), 127-137.

Putri, F. R., Sulastri, D., \& Lestari, Y. (2015). Faktor-faktor yang berhubungan dengan Status Gizi Anak Balita di wilayah kerja Puskesmas Nanggalo Padang. Jurnal Kesehatan Andalas, 4(1), 254-261.

Ratufelan, E., Zainuddin, A., \& Junaid. (2018). Hubungan Pola Makan, Ekonomi Keluarga dan Riwayat
Infeksi dengan Kejadian Gizi Kurang pada Balita di wilayah kerja Puskesmas Benu-benua Tahun 2018. Jurnal Ilmiah Mahasiswa Kesehatan Masyarakat, 3(2), 1-13.

Rohimah, E., Kustiyah, L., \& Hernawati, N. (2015). Pola Konsumsi, Status Kesehatan dan hubungannya dengan Status Gizi dan Perkembangan Balita. J. Gizi Pangan, 10(2), 93-100. https://doi.org/10.25182/jgp.2015.10. 2.\% $25 \mathrm{p}$

Rumende, M., Kapantow, N. H., \& Punuh, M. I. (2018). Hubungan antara Status Sosial Ekonomi di Kecamatan Tombatu Utara Kabupaten Minahasa Tenggara. Jurnal Kesmas, 7(4).

Salmah, S. (2018). Pengantar Ilmu Kesehatan Masyarakat. Jakarta: CV. Trans Info Media.

Sholikah, A., Rustiana, E. R., \& Yuniastuti, A. (2017). Faktor-faktor yang berhubungan dengan Status Gizi Anak Balita di Pedesaan dan Perkotaan. Public Health Perspective Journal, 2(1), 9-18.

Supariasa, I. D. N., Bakri, B., \& Fajar, I. (2016). Penilaian Status Gizi (Edisi 2). Jakarta: EGC.

Suryani, L. (2017). Faktor yang mempengaruhi Status Gizi Balita di wilayah kerja Puskesmas Payung Sekaki Pekanbaru. Journal of Midwifery Science, 1(2), 47-53.

The World Bank. (2018). Prevalence of Underweight, Weight for Age. The World Bank Group.

UNDP. (2018). The Sustainable Development Goals.

UNICEF. (2018). Malnutrition rates remain alarming: stunting is declining too slowly while wasting still impacts the lives of far too many young children.

WHO. (2017). Children: reducing mortality. 